\title{
REKONTEKSTUALISASI PEMIKIRAN SEYYED HOSSEIN NASR TENTANG BANGUNAN ILMU PENGETAHUAN DAN PENDIDIKAN ISLAM
}

\author{
Asfa Widiyanto \\ Institut Agama Islam Negeri Salatiga, Indonesia \\ E-mail: widiyanto_asfa@daad-alumni.de
}

\begin{abstract}
This article discusses the conception of science and its significance for the reconstruction of Islamic education, by analyzing and contextualizing the thoughts of Seyyed Hossein Nasr. Nasr is considered a figure who has competence in history of science and philosophy with special emphasis on Islamic science and philosophy. In the earlier phase of his life, he acquainted himself with the thoughts of prominent thinkers both from East and West, and with the very issue of the encounter between East and West. This position makes the thoughts of Nasr on science having their distinctive character. The first part of this paper investigates the construct and characteristics of Islamic science as well as the hierarchy and the idea of unity in Islamic science. The second part of this paper is dealing with the reformulation of philosophical basis of Islamic education, most specifically in the domain of ontology, epistemology and axiology. The third is dealing with the attempts of reconstructing the system of Islamic education, most notably pertaining to the aim of education, educator, student, means of education, and milieu of education.
\end{abstract}

Keywords: Construct of science; reconstruction of Islamic education; philosophical basis of Islamic education.

\section{Pendahuluan}

Seyyed Hossein Nasr merupakan cendekiawan yang piawai dalam bidang filsafat dan sejarah ilmu, serta sosok yang otoritatif untuk berbicara tentang perjumpaan antara tradisi dan modernitas, Timur dan Barat. Posisi ini, ditambah perspektif tradisionalnya, menjadikan pemikiran Nasr tentang ilmu mempunyai karakter tersendiri.

Nasr menekuni bistory of science and philosophy, dengan titik tekanan pada Islamic science and philosophy di Universitas Harvard hingga meraih 
gelar PhD tahun 1958. ${ }^{1}$ Reputasinya sebagai seorang sarjana dan ahli ilmu Islam dapat dilihat dari sejumlah besar buku mengesankan yang ditulisnya. Tulisan-tulisanya, antara lain Knowledge and the Sacred, The Need for a Sacred Science, dan Science and Civilization in Islam, menunjukan secara jelas bahwa ia merupakan salah seorang yang berkompeten untuk berbicara mengenai bangunan ilmu yang berbasiskan spiritual.

Dengan bertitik tolak dari sisi lemah konsepsi manusia modern terutama di Barat tentang ilmu, Nasr berusaha merekontruksi bangunan ilmu Islam, yang didasarkan pada ide kesatuan, yang merupakan jantung wahyu Islam. ${ }^{2}$ Hierarki ilmu, menurut Nasr, dijaga utuh dalam Islam, dan scientia senantiasa digali dari dada sapientia, sehingga wilayah fisik diterima dalam rangka menjaga kebebasan ekspresi dan realisasi wilayah spiritual. ${ }^{3}$

Konsepsi ilmu Nasr tersebut menarik untuk dikaji terutama sekali dalam kaitannya dengan pendidikan. Pendidikan Islam yang saat ini juga mengalami krisis, antara lain karena kebingungannya dalam menghadapi sistem pendidikan modern sehingga meninggalkan visi hierarkis dan kesalinghubungan antara berbagai disiplin ilmu yang memungkinkan realisasi kesatuan dalam kemajemukan, kiranya membutuhkan konsepsi ilmu yang mencerahkan dan membebaskan, sehingga mampu mewujudkan manusia paripurna (al-insân al-kâmið).

Dalam hal ini menarik untuk disimak pernyataan Nasr tentang pendidikan Islam modern: "Kekacauan yang mewarnai kurikulum pendidikan modern dikebanyakan negara Islam sekarang ini, dalam banyak hal, disebabkan oleh hilangnya visi hierarkis terhadap pengetahuan seperti yang dijumpai dalam sistem pendidikan tradisional". ${ }^{4}$

\section{Bangunan dan Karakteristik Ilmu Islam}

Ilmu Islam bukanlah sesuatu yang lahir begitu saja. Ia merupakan hasil persinggungan Islam dan umat Islam dengan peradabanperadaban tua seperti Yunani, Persia, India, Kalde dan Cina. Dalam mempelajari ilmu yang ada dalam peradaban tersebut, orang-orang Islam mengambil beberapa unsur dari masing-masing peradaban

${ }^{1}$ Pervez Hoodbhoy, Islam and Science (Malaysia: S. Abdul Majeed \& Co, 1993), 127.

2 Seyyed Hossein Nasr, Science and Civilization in Islam (New York: The New American Library, 1970), 27.

${ }^{3}$ Giorgio de Santillana, "Preface", dalam Seyyed Hossein Nasr, Science and Civilization in Islam (New York: The New American Library, 1970), 2.

4 Seyyed Hossein Nasr, "Kata Pengantar", dalam Osman Bakar, Hierarki Ilmu: Membangun Kerangka Pikir Islamisasi Ilmu, terj. Purwanto (Bandung: Mizan, 1997), 11. 
tersebut dan menggabungkan ilmu ini ke dalam satu corpus baru, yang kemudian tumbuh abad demi abad dan menjadi bagian peradaban Islam serta diintegrasikan ke dalam struktur dasar yang diuraikan dari wahyu ilahi. ${ }^{5}$

Secara ontologis, ilmu Islam dapat dikatakan bersifat simbolis. Alam, dalam pandangan Islam, adalah lambang yang harus dipahami secara simbolis, sehingga hubungan dengan realitas yang lebih tinggi tidak hilang, begitu juga hubungan antarmereka. Dengan demikian, alam tidak bisa direduksi menjadi sekedar "fakta". ${ }^{6}$ Fungsi tertinggi ilmu Islam adalah membantu intelek dan instrumen-instrumen persepsi untuk melihat dunia dan semua tingkatan eksistensi, bukan sebagai fakta atau objek namun sebagai simbol, sebagai cermin yang dengannya terrefleksikan wajah Tercinta, yang darinya semua berasal dan kepadanya semua kembali. $^{7}$

Dalam dataran epistemologi, ilmu Islam berlandaskan pada iluminasi akal oleh intelek. ${ }^{8}$ Intelek adalah alat, akal adalah aspek positifnya dan refleksinya pada dunia manusia. Intelek adalah dasar akal, dan latihan akal sekiranya sehat dan normal dengan sendirinya akan sampai pada intelek. Itulah sebabnya fisikawan Muslim menyatakan bahwa ilmu rasional secara alamiah akan membimbing orang mengakui keesaan Ilahi.

Intelek, menurut Nasr, adalah kepasitas mata batin, namun seringsering diidentikkan dengan fungsi analitis pikiran sehingga hampir tidak ada sangkut pautnya dengan sikap kontemplatif. Pereduksian makna intelek ini menimbulkan sikap menaklukan dan menguasai alam dengan kekuatan konsep. Padahal seharusnya hubungan antara ilmuwan (Muslim) dengan alam bersifat intelektif, tidak abstrak, tidak analistik dan tidak sentimental. ${ }^{9}$

Terma intelek, sebagaimana dimaksud oleh Nasr, dapat ditelusuri akar dan penggunaannya pada term-term al-Qur'ân semisal qalb, fu'âd, dan basîrah. Qalb, sebagaimana fu'âd, yang memiliki muatan makna yang identik dengan qalb, sering digunakan al-Qur'ân untuk menyebut alat untuk memahami realitas dan nilai-nilai. Dari hal itu, term intelek bisa disandingkan maknanya dengan qalb dan fu'âd, atau lebih khusus

\footnotetext{
${ }^{5}$ Nasr, Science and Civilization in Islam, 30.

${ }^{6}$ Ibid., 24.

7 Seyyed Hossein Nasr, Knowledge and the Sacred (Edinburg: Edinburg University Press, 1981), 191.

${ }^{8}$ Ibid., 38.

${ }^{9}$ Nasr, Science and Civilization in Islam, 24.
} 
lagi, basîiah. Namun, Nasr sering menggunakan kata 'aql untuk menunjuk intelek. Hal ini dapat dipahami jika meletakannya dalam (keseluruhan) tradisi intelektual Islam. Dalam tradisi intelektual Islam, kata 'aql digunakan untuk menunjukan intelek dan akal, namun antara kedua istilah tersebut, akal dan intelek, ada pembedaan yang jelas. AlFarâbî, misalnya, menyatakan bahwa intelek adalah prinsip akal, dalam pengertian akal merupakan buah karya intelek. Sebagian pemikir setelah periode al-Farâbî menggunakan istilah al-'aql al-kullîy untuk menyatakan intelek dan al-'aql al-juz'ŷy untuk akal. Intelek adalah alat yang digunakan pemahaman intuitif untuk mencapai kebenarankebenaran transenden, sementara akal merupakan instrumen pemikiran diskursif $(\text { fikr })^{10}$

Sedangkan dalam dataran aksiologis, ilmu Islam pada akhirnya berusaha mencapai ilmu yang akan memberikan saham untuk kesempurnaan spiritual dan keselamatan orang yang sanggup mengkajinya sehingga nilainya lebih sukar dikenali. Dengan demikian terlihat bahwa ilmu dalam Islam tidak bebas nilai (value bond), sebab bila ilmu itu bebas nilai akan menimbulkan kesulitan bahkan kekacauan, karena pemilik ilmu tidak mempunyai tanggung jawab moral untuk memanfaatkan ilmu dalam rangka nilai-nilai tertentu. Karena ajaran-ajaran Islam pada prinsipnya bersifat Gnostik, maka semua bentuk ilmu, bahkan yang paling eksternal sekalipun, memiliki ciri sakral sepanjang ia setia pada prinsip-prinsip wahyu.

\section{Hierarki Ilmu dan Ide Kesatuan dalam Islam}

Kesatuan antara Tuhan dan alam merupakan prinsip utama yang mengatur kehidupan intelektual Islam. Tuhan menciptakan alam dalam keserasian yang sempurna dan seluruh bagian alam yang saling berkaitan menggambarkan keesaan Tuhan. Satu model kosmologi Islam menganggap alam sebagai bangunan yang terdiri dari beberapa lapisan, dengan catatan bahwa, secara metafisik, realitas itu pada dasarnya satu. ${ }^{11}$

Kaum sufi, dengan berdasarkan keterangan al-Qur'ân, memformulasikan doktrin "lima keberadaan Ilahi" untuk menggambarkan hierarki realitas. Tiga realitas pertama adalah nâsût (dunia fisik, yang didominasi oleh manusia), malakêt (dunia fisik dan manifestasi subtil) dan jabarût (dunia yang dipahami atau dunia subtansi malaikat). Urutan ini merupakan tiga "keberadaan" yang pertama dalam urutan

${ }^{10}$ Bakar, Hierarki Ilmu, 98.

${ }^{11}$ Nasr, Science and Civilization in Islam, 93. 
menaik. Tingkat realitas selanjutnya adalah sifat-sifat Ilahiah (Asmâ' Sifa >tîah) yang dapat dipersamakan dengan "Akal Universal" atau "Wujud Murni", yaitu prinsip-prinsip ontologisme dari keseluruhan kosmos, dan karena itu merupakan yang absolut terhadap seluruh ciptaan. Keberadaan selanjutnya dan yang tertinggi adalah esensi Ilahi (al-Dhât) yang merupakan diri tertinggi dan tak terbatas, wujud tak tergapai yang merupakan prinsip "tak dapat disifati" (ghayr muwassaf) dan "tak dapat ditentukan" (ghayr mu'ayyan), dan oleh karenanya absolut. ${ }^{12}$

Dengan demikian terlihat bahwa ada tiga struktur fundamental kosmos tradisional, yang tersusun secara hierarkis, yaitu material (nâsût), psikis (malakût), dan spiritual (jabarût). Perspektif kosmologis semacam ini merupakan konsekuensi penting dari pengukuhan tauhid bahwa manusia harus menerima realitas objektif alam semesta. Sebagai sumber pengetahuan, agama bersifat empatik ketika menyatakan bahwa segala sesuatu di alam semesta ini saling berkaitan dalam jaringan kesatuan alam melalui hukum-hukum kosmis yang mengatur mereka. Kosmos terdiri dari berbagai tingkatan realitas, namun ia membentuk suatu kesatuan karena ia mesti memanifestasikan ketunggalan sumber dan asal-usul metafisiknya yang dalam bahasa agama disebut Tuhan. Pada kenyataannya, al-Qur'ân dengan tegas menekankan bahwa kesatuan kosmos merupakan bukti yang jelas akan keesaan Tuhan.

Realitas kosmik tersebut merupakan kutub objektif epistemologi Islam, dan hubungan antara hierarki kutub subjektif dan kutub objektif pengetahuan adalah korespondensi satu-satu. Setiap tingkatan realitas kosmik memiliki eksistensi yang bersesuian dalam diri manusia. Struktur tripartite kosmos tradisional yang terdiri dari alam material, psikis, dan spiritual bersesuaian dengan tripartite mikrokosmos manusia tradisional yang terdiri dari tubuh (corpus, jism), jiwa (anima, psyche, nafs) dan ruh (spirit).

Dalam perspektif ini, alam dapat dilihat sebagai teks, mirip dengan al-Qur'ân, yang membawa kebenaran, tetapi harus ditafsirkan dengan menggunakan fakultas-fakultas mental (mental faculties) seperti akal, daya kontemplasi dan intuisi, yang kesemuanya disinari wahyu alQur'ân. Dipandang sebagai teks, alam adalah jalinan simbol yang harus dibaca menurut maknanya. Al-Qur'ân adalah padanan teks tersebut dalam kata-kata manusia, kalimat-kalimatnya disebut âyât

12 Ibid. 
(tanda-tanda). Alam dan al-Qur'ân keduanya menegaskan kehadiran Tuhan. ${ }^{13}$

Dengan demikian pandangan Islam terhadap ilmu, sebagaimana berkembang dan dirumuskan pada masa klasik, berkaitan dengan asumsi bahwa penelitian ilmiah terikat oleh dua prinsip kesatuan dan hierarki tak ada wujud yang tidak berkaitan secara fisik atau simbolis dengan setiap benda lain di alam raya, dan hubungan ini ditentukan melalui suatu hierarki yang berlandaskan agama. Kebenaran dan realitas hanya dalam bentuk simbolis saja. Oleh karena itu, setiap makhluk mempunyai esensi kualitatif dan kuantitatif. Dalam tatanan kosmologi benda-benda, esensi kualitatif lebih bernilai dan lebih penting dari dimensi karakter fisik apapun.

Ilmu, sebagaimana juga seni, dalam Islam berdasarkan ide kesatuan (unity) yang merupakan inti wahyu Islam, semisal Alhambra atau Masjid Paris, yang melahirkan bentuk plastis yang dapat membuat orang merenungkan keesaan Ilahi dalam manifestasi multiplisitas. Begitu pula semua ilmu yang pantas disebut bersifat Islam menunjukan kesatupaduan alam. Kita dapat mengatakan bahwa tujuan dari semua ilmu Islam dan lebih umum lagi, dari semu ilmu (kosmologis) abad pertengahan dan zaman kuno dari segala yang ada sehingga dengan merenungkan kesatun kosmos, orang dapat menuju ke arah kesatuan dasar Ilahi yang dibayangkan dalam kesatuan alam. ${ }^{14}$ Dengan demikian terlihat bahwa peradaban Islam menempatkan ilmu pengetahuan terkait dengan prinsip keesaan Ilahi (al-tawhîid), sehingga visi keilahian nampak dan melingkupi semua ilmu pengetahuan. Hal ini berbeda dari peradaban Barat yang mereduksi visi keilahian ilmu, sehingga menimbulkan krisis kemanusiaan dan lingkungan.

Salah satu aspek penting dalam pandangan dunia Islam adalah bahwa alam dan segala isinya bersifat hierarkis. Alam mempunyai susunan dan hierarki yang lengkap, dari langit yang ke sembilan hingga batu yang terbenam jauh dalam bumi, dan dari susunan itu tercermin dalam hukum dan ketertiban masyarakat. ${ }^{15}$ Hierarki itu juga terlihat dalam hierarki kesucian (taxis hiera) dan hierarki ilmu. Hierarki ilmu tetap dipertahankan dalam Islam, karena hierarki pengetahuan dalam Islam-seperti terdapat dalam sejarah—tergabung oleh ikatan metafisis; bagaikan sumbu vertikal yang mempersatukan bidang-

\footnotetext{
${ }^{13}$ Ibid., 24.

14 Ibid., 21-22.

${ }^{15}$ Nasr, Knowledge and the Sacred, 190.
} 
bidang referensi horizontal "dari atas" di mana integrasi semua pandangan yang berbeda adalah mungkin. ${ }^{16}$

\section{Reformulasi Basis Filosofis Ilmu Pendidikan Islam}

IImu pendidikan Islam, sebagai sebuah ilmu pendidikan yang berbasis pada pandangan dunia (Welstanchaunng) Islam, disinyalir pakar sebagai suatu ilmu yang niscaya keberadaannya, terutama sekali dalam memberikan alternatif bagi krisis konseptual yang melanda dunia pendidikan. Adalah sangat urgen untuk menggunakan pandangan dunia Islam untuk melihat dan menyoroti fenomena pendidikan, sehingga darinya terwujud ilmu pendidikan Islam.

Ilmu pendidikan Islam, sebagai sebuah ilmu yang baru, sampai sekarang masih memerlukan banyak penyempurnaan terutama sekali dari aspek landasan filosofisnya; sesuatu yang substansial dan merupakan tiang penyangga sebuah ilmu. Terdapat pertanyaan terkait apakah ilmu pendidikan Islam, saat ini, sudah bisa dikatakan sebagai sebuah ilmu. Jika melihat khazanah filsafat ilmu, paling tidak ada beberapa kriteria ilmu yang disampaikan oleh para pakar. Beerling, misalnya, mendefinisikan ilmu sebagai pengetahuan yang mempunyai dasar pembenaran, bersifat sistematis dan intersubjektif. ${ }^{17}$ The Liang Gie menyatakan bahwa ilmu mencakup tiga dimensi, yaitu pengetahuan sistematis, aktivitas dan metode. ${ }^{18}$ Sementara itu, Archie $\mathrm{J}$. Bahm mengemukakan enam komponen utama ilmu yang terdiri dari problem, sikap, metode, aktivitas, kesimpulan dan pengaruh, ${ }^{19}$ yang kesemuanya merupakan satu kesatuan integral dan integratif.

Analisis lebih tajam tentang hal ini bisa dilihat pada pemikiran Noeng Muhadjir, sebagaimana dikutip Achmadi, ${ }^{20}$ yang menyatakan bahwa ilmu pendidikan Islam baru menampakkan dirinya sebagai ilmu yang berdiri sendiri setelah terpenuhi syarat-syarat berikut:

1. Memiliki objek studi yang eksplisit dari disiplin ilmu lain;

2. Memiliki struktur atau sistematika yang juga eksplisit dari disiplin ilmu lain;

3. Memiliki metode pengembangan;

\footnotetext{
${ }^{16}$ Nasr, Science and Civilization in Islam, 38.

17 Beerling, Pengantar Filsafat Ilmu, terj. Soejono Soemargono (Yogyakarta: Tiara Wacana, 1990), 6.

18 The Liang Gie, Ilmu dalam Perspektif Moral, Sosial, dan Politik (Yogyakarta: Liberty, 1991), 86-96.

${ }_{19}$ Archie J. Bahm, Axiology (New York: World Books, 1980), 14.

20 Achmadi, Ilmu Pendidikan Islam 1 (Salatiga: Fakultas Tarbiyah IAIN Walisongo Salatiga, 1987), 26.
} 
4. Memiliki evidensi empirik.

Melihat hal itu kiranya perlu diajukan pertanyaan yang esensial, apakah ilmu pendidikan Islam telah memenuhi syarat-syarat tersebut? Dalam dataran filosofis, juga perlu dipertanyakan apakah ilmu pendidikan Islam yang mengklaim sebagai disiplin ilmu yang mandiri telah mempunyai pandangan dunianya sendiri baik secara ontologis, epistemologis maupun aksiologis? ${ }^{21}$ Landasan filosofis ilmu pendidikan Islam, dengan demikian menjadi sangat urgen karena dengannyalah sebuah ilmu mendapatkan analisis, penjelasan dan dasar-dasar yang memadai tentang keberadaan ilmu itu sendiri. Keberadaan sebuah ilmu, dalam perspektif filsafat ilmu, paling tidak, bertumpukan pada tiga komponen utama, yaitu ontologi, epistemologi dan aksiologi. Karenanya upaya menemukan bangunan ilmu pendidikan Islam tanpa memberikan perhatian dan apresiasi memadai tentang ketiga komponen tersebut akan menjadi tidak bermakna karena tidak menyentuh ke dasar persoalan dan cenderung dangkal.

Koento Wibisono ${ }^{22}$ menjelaskan bahwa ontologi ilmu meliputi apa hakikat ilmu, kebenaran dan kenyataan yang inheren dengan pengetahuan ilmiah, dan tidak terlepas dari persepsi filsafat tentang apa dan bagaimana "yang ada" itu (being, sein, het rijn). Dalam konteks ini, ilmu pendidikan Islam secara ontologis berlandaskan metafisika Islam yang mengakui bahwa alam itu mempunyai mempunyai kualitas-kualitas kesucian (sacred qualities), ada hierarki dan kesalinghubungan antarrealitas, serta mengakui adanya waktu kausal (causal time) dan waktu akausal (acausal time). Landasan metafisik tersebut tentunya membuat substansi ilmu pendidikan Islam, terutama sekali yang dikembangkan Nasr, berbeda dari ilmu pendidikan secara umum.

Nasr mengandaikan ilmu pendidikan Islam yang tersinari oleh ruh eternalitas (keabadian), di mana semangat eternalitas ini harus selalu terintegrasikan dalam semua aspek pendidikan. ${ }^{23}$ Dengan demikian, jika kita tarik dan kaji lebih lanjut, dapat dilihat bahwa sebenarnya substansi ilmu pendidikan Islam itu mencakup beberapa poin pokok,

21 Ismail SM, et al., Paradigma Pendidikan Islam (Semarang: Pustaka Pelajar dan Fakultas Tarbiyah IAIN Walisongo, 2001), xi.

${ }^{22}$ Koento Wibisono, "Ilmu Pengetahuan Sebuah Sketsa Umum Mengenai Kelahiran dan Perkembangannya sebagai Pengantar untuk Memahami Filsafat Ilmu”, Makalah, Ditjen Dikti Depdikbud-Fakultas Filsafat UGM Yogyakarta, 1999, 1.

23 Abdul Rohman, "Pendidikan Islam 'Tradisional' di Era Modem”, dalam Ruswan Thoyib dan Darmuin (eds.), Pemikiran Pendidikan Islam (Yogyakarta: Pustaka Pelajar, 1999), 311. 
yakni berlandaskan pada metafisika Islam, bersemangatkan eternalitas, dan termanifestasikan dalam totalitas aktivitas pendidikan Islam yang memperhatikan aspek-aspek pendidikan yang meliputi akal, hati dan spiritual secara seimbang.

Khusus mengenai totalitas aktivitas pendidikan ini mungkin bisa disandingkan dengan paradigma tauhid, yang bukan berarti hanya mengesakan Tuhan, namun mengintegrasikan seluruh aspek, seluruh pandangan dan aspek kehidupan dalam sistem dan lapangan kehidupan sosial kita. Dalam konteks pendidikan (Islam), harus ada keselarasan, kesatuan atau unifikasi antara aspek-aspek lahir (eksoteris) dan batin (esoteris) atau dalam istilah pendidikan, misalnya, antara aspek kognitif, aspek afektif, aspek emosional spiritual dan aspek psikomotorik yang mendukung terjadinya aktivitas. Dalam konteks pendidikan Islam, mungkin, adalah keterpaduan antara aspek akal, iman, qalb, dan amal. ${ }^{24}$

Substansi ilmu pendidikan Islam yang demikian dapat kita korelasikan dengan pendapat Syed Muhammad Naquib al-Attas yang menyatakan bahwa unsur fundamental dari pendidikan Islam adalah ta'dîb, yang menurutnya merupakan pengertian yang mencakup kehidupan spiritual dan material manusia yang memberikan sifat kebaikan kepadanya dan lebih representatif untuk menunjuk pendidikan Islam. Hal ini karena terma ta'dîb secara konseptual sudah mencakup ilm, ta'lim dan tarbiyah. Secara lebih tegas, al-Attas mendefinisikan pendidikan Islam sebagai: "Pengenalan dan pengakuan yang secara berangsur-angsur ditanamkan ke dalam manusia tentang tempat-tempat yang tepat dari segala sesuatu di dalam tatanan penciptaan sedemikian rupa, sehingga hal ini membimbing ke arah pengenalan dan pengakuan tempat Tuhan yang tepat di dalam tatanan wujud." 25

\footnotetext{
${ }^{24}$ Azyumardi Azra, "Rekonstruksi Kritis Ilmu dan Pendidikan Islam", dalam M. Anies (ed.), Religiusitas IPTEK (Yogyakarta: Pustaka Pelajar, 1998), 91-92.

25 Syed Muhammad Naquib Al-Attas, Konsep Pendidikan dalam Islam, terj. Haidar Baqir (Bandung: Mizan, 1994), 62. Al-Attas, merupakan salah satu pakar yang gigih memperjuangkan terma ta'dî̀ untuk menunjukkan substansi pendidikan Islam. Oleh karena itu, First World Conference on Moslem Education di Mekah merekomendasikan antara lain sebagai berikut: "Makna pendidikan dalam totalitasnya, dalam konteks Islam, terkandung dalam konotasi istilah tarbiyah, ta'lìm dan ta'dîb secara bersamasama". Lihat Ahmad Ludjito, "Pendekatan Integralistik Pendidikan Agama", dalam Chabib Thoha (ed.), Reformulasi Filsafat Pendidikan Islam (Yogyakarta: Pustaka Pelajar, 1996), 298.
} 
Ta'dîb berakar dari kata adab yang secara konseptual mencakup ilmu dan amal. Penekanan pada adab yang mencakup ilmu dan amal ini bertujuan agar ilmu digunakan secara baik. Ta'dîb, menurut alAttas, lebih merepresentasikan pandangan dunia Islam, berbeda dari tarbiyah yang secara esensial lebih berorientasi fisik-material. Tarbîyah, menurutnya tidak secara alami mengandung unsur-unsur pengetahuan, intelegensia dan kebajikan yang pada hakikatnya merupakan unsur-unsur pendidikan Islam yang sebenarnya. ${ }^{26}$ Dengan demikian substansi ilmu pendidikan Islam menurut al-Attas menunjuk pada dimensi material dan spiritual yang diterapkan secara proporsional menurut hierarkinya untuk mencapai tujuan pendidikan Islam. Dari hal itu, bisa kita tarik pemahaman bahwa substansi ilmu pendidikan Islam yang dikembangkan al-Attas hampir senada dengan yang dikemukakan Nasr, yaitu meliputi beberapa poin pokok; berlandaskan metafisika Islam yang mengakui adanya hierarki realitas dan pengetahuan dan berusaha mengembangkan potensi fisik, intelektual serta rohaniah seseorang.

Secara lebih luas, sebenarnva dalam diskursus pendidikan Islam, terdapat perbedaan pendapat apakah pendidikan Islam itu lebih terwakili dengan terma tarbîyah, ta'lim atau ta'dîb. Abdurrahman anNahlawi, sebagaimana dikutip Tafsir, misalnya, lebih cenderung menggunakan kata tarbîyah untuk pendidikan. Ia lebih lanjut menyatakan bahwa kata tarbîyah berasal dari tiga kata, yaitu, petama,

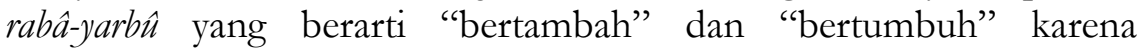
pendidikan mengandung misi untuk menambah bekal pengetahuan kepada anak didik dan menumbuhkan potensi yang dimilikinya. Kedua, dari kata rabiya-yarbâ yang berarti "menjadi besar" karena pendidikan juga mengandung misi untuk membesarkan jiwa dan memperluas wawasan seseorang. Ketiga, dari kata rabba-yarubbu yang berarti "memperbaiki, menguasai urusan, menuntun, menjaga, dan memelihara".

Abdul Fattah Jalal berpendapat bahwa istilah yang tepat untuk mewakili kata pendidikan adalah talim, yang menurutnya lebih universal dibanding istilah tarbîyah. Untuk ini Jalal mengajukan alasan bahwa kata tallim berhubungan dengan memberikan bekal pengetahuan. Pengetahuan ini dalam Islam dinilai sebagai sesuatu

26 Al-Attas, Konsep Pendidikan dalam Islam, 59, 64-74.

27 Ahmad Tafsir, Ilmu Pendidikan dalam Perspektif Islam (Bandung: Remaja Rosdakarya, 1994), 29. 
yang memiliki kedudukan yang tinggi. Hal ini misalnya dapat dijelaskan dalam kasus Adam yang diberikan ta'lim oleh Tuhannya (Q.S. al-Baqarah: 30-34). Dan juga kenyataan bahwa salah satu tugas Muhammad adalah mendidik dengan kitab dan hikmah (Q.S. alBaqarah: 151). Hal ini berbeda dari terma tarbîyah yang menurutnya menunjuk pada proses persiapan dan pengasuhan pada fase pertama pertumbuhan manusia, atau menurut istilah sekarang, fase bayi dan kanak-kanak (Q.S. al-Isrâ' [17]: 24 dan Q.S. al-Shu'arâ' [26]: 18). ${ }^{28}$

Objek ilmu pendidikan Islam mencakup Tuhan, manusia dan alam, yang dikaji secara proporsional. Khusus untuk objek manusia, ilmu pendidikan Islam, dalam perspektif Nasr, mengambil model suatu masa yang disebut "Islam tradisional", yaitu Islam yang masih terintegrasi secara kuat antara dimensi spiritual dan dimensi intelektual yang secara kuat bersumber pada pemahaman wahyu Ilahi. ${ }^{29}$ Dalam kaitannya dengan hal itu, Achmadi ${ }^{30}$ menyatakan bahwa objek ilmu pendidikan adalah manusia dalam kaitannya dengan situasi pendidikan. Adapun yang membedakan antara objek studi ilmu pendidikan dengan ilmu lain adalah pada segi upaya dan tujuan normatifnya. Sedangkan perbedaan objek studi ilmu pendidikan umum dengan ilmu pendidikan Islam adalah bahwa dalam ilmu pendidikan Islam, nilai-nilai Islamlah yang dijadikan normanya.

Melihat hal itu, sebenarnya tidak terdapat perbedaan yang signifikan antara objek studi ilmu pendidikan Islam yang ditawarkan Nasr dan Achmadi. Kalaulah menurut Achmadi objek studi ilmu pendidikan Islam adalah "manusia dalam kaitannya dengan situasi pendidikan", hal itu tidak berarti ia menafikan Tuhan dan alam sebagai objek ilmu pendidikan Islam, namun Tuhan dan alam tersebut tercakup dalam frase "dalam kaitannya dengan situasi pendidikan". Perbedaan yang justru terlihat adalah bahwa karena perspektif perenialnya, Nasr melihat bahwa objek manusia dalam ilmu pendidikan Islam mengambil model "Islam tradisional".

Epistemologi, secara terminologis, berarti branch of philosophy which is concerned with the nature and scope of knowledge, its presuppositions and basis

\footnotetext{
19 Abdul Fattah Jalal, Asas-asas Pendidikan Islam, terj. Herry Noer Ali (Bandung: Diponegoro, 1988), 25-28.

29 Bernard Lewis, Islam and the West (New York: Oxford University Press, 1993), 136.

30 Achmadi, "Islam sebagai Paradigma Ilmu Pendidikan”, dalam Ismail SM (ed.), Paradigma Pendidikan Islam (Yogyakarta: Pustaka Pelajar, 2001), 25-26.
} 
and the general reliability of claims to knowledge. ${ }^{31}$ Epistemologi ilmu, dengan demikian, meliputi sumber, sarana, dan tata cara menggunakan sarana tersebut untuk mencapai pengetahuan ilmiah, serta tolok ukur pengetahuan ilmiah. ${ }^{32}$ Secara umum bisa dikatakan bahwa epistemologi ilmu pendidikan Islam yang dikembangkan Nasr bercorak teosentris. Epistemologi tersebut dikembangkan atas tiga sumber pengetahuan yakni wahyu, intelek dan akal, yang saling terkait antara satu dengan yang lainnya. Wahyu sebagai ayat Tuhan yang terucapkan, intelek yang mengandung konotasi kapasitas mata batin yang bisa menangkap pengetahuan dan Divine Intellect, dan akal sebagai refleksi intelek yang terutama sekali berfungsi untuk memahami (fenomena) alam membuat ilmu pendidikan Islam mempunyai karakter tersendiri.

Adapun aksiologi dimaknai dengan modern term for theory of value (the desired, preferred, good), investigation of its nature, criteria, and metaphysical statuses. ${ }^{33}$ Dengan kata lain, aksiologi merupakan pengetahuan yang menyelidiki hakikat nilai ditinjau dari segi filsafat. ${ }^{34}$ Aksiologi ilmu meliputi nilai-nilai yang bersifat normatif dalam pemberian makna terhadap kebenaran atau kenyataan, dan merupakan kondisi sine qua non yang wajib ditaati baik dalam melakukan penelitian maupun dalam menerapkan ilmu. ${ }^{35}$ Gunnar Myrdal, sebagaimana dikutip Achmadi, ${ }^{36}$ menekankan pentingnya pertimbangan nilai dalam ilmu sosial, termasuk di dalamnya pendidikan. Sementara itu Noeng Muhadjir, sebagaimana dikutip Shodiq Abdullah, ${ }^{37}$ menyatakan karena ilmu pendidikan Islam sebagian objeknya bersifat normatif, maka dari itu harus diorientasikan pada nilai. Oleh karena itu, telaah empirik kependidikan setiap kali perlu dikaji ulang agar keterkaitan atau tidaknya dengan nilai tertentu dapat dievaluasi.

31 Paul Edward (ed.), Encyclopedia of Philosophy, Vol. 3 (New York: Macmillan Publishing Company 1972), 9.

32 Wibisono, "Ilmu Pengetahuan", 12.

${ }^{33}$ Degobert D. Runes, Dictionary of Philosophy (New Littlefield: Adam and Co, 1971), 32.

${ }^{34}$ Louis O. Kattsoff, Pengantar Filsafat, terj. Soejono Soemargono (Yogyakarta: Tiara Wacana, 1992), 327.

35 Wibisono, "Ilmu Pengetahuan", 12.

36 Ahmadi, "Islam sebagai Paradigma Ilmu Pendidikan", 23.

37 Shodiq Abdullah, "Rekonsiliasi Epistemologi: Ikhtiar dalam Mengatasi Dikhotomi Ilmu dalam Pendidikan Islam", Abdul Khaliq, dkk (ed.), Paradigma Pendidikan Islam (Yogyakarta: Pustaka Pelajar, 2001), 102-103. 
Secara aksiologis, ilmu pendidikan Islam berlandaskan pada nilainilai Ilahiah, atau nilai-nilai tradisional, menurut istilah Nasr. Tradisi, salah satu kata kunci pemikiran Nasr, perlu dipahami secara benar karena istilah tersebut sering direduksi pengertiannya oleh orangorang modern sebagai warisan pemikiran, adat, kebiasaan dan sebagainya. Tradisi berarti kebenaran dari karakter supra-individual yang berakar dalam hakikat dari realitas sedemikian rupa, sebab, tradisi-yang dimaksudkan oleh Nasr-bukanlah mitologi yang kekanak-kanakan tetapi ia merupakan sains yang nyata“.38

Tradisi, lanjut Nasr, berarti kebenaran atau prinsip dari suatu asal yang bersifat Ilahiah (a divine origin) yang disampaikan dan diwahyukan kepada umat melalui dan, pada kenyataannya, kepada seluruh jagad raya melalui berbagai tokoh yang dipandang sebagai nabi, rasul, logos dan agen-agen penerus yang lain. Termasuk dalam tradisi ini adalah seluruh percabangan dan aplikasi prinsip ini dalam wilayah yang berbeda-beda meliputi struktur sosial, seni, simbol-simbol, sains dan mencakup juga Pengetahuan Tertinggi beserta cara memperolehnya. ${ }^{39}$

Dalam kaitannya dengan hal itu, perlu dikemukakan pemikiran Noeng Muhadjir ${ }^{40}$ yang berusaha membangun paradigma filosofis ilmu pendidikan Islam. Bangunan paradigmatis keilmuan pendidikan Islam tersebut didasarkan pada tiga elemen dasar, yaitu asumsi dasar, postulasi dan tesis-tesis tentang filsafat ilmu. Pertama adalah tataran asumsi. Asumsi dasar yang dipakai adalah pandangan Realisme Metafisik, yakni aliran filsafat yang disamping mengakui adanya realitas yang tidak sensual-empirik juga mengakui adanya keteraturan alam semesta, karena keteraturan tersebut adalah milik Allah.

Kedua adalah tataran postulasi. Postulasi dimaksud adalah pada tataran ontologisnya, yaitu bahwa keteraturan tersebut tampil dalam eksistensi kebenaran yang multi faset atau multi strata yang hakikatnya adalah tunggal, yaitu eksistensi sensual, logis, etis dan transenden yang paralel dengan âyah, ishârah, budan dan raḥmah dalam istilah al-Qur'ân. Dalam hal ini, aliran filsafat yang secara eksplisit mengakui yang transenden adalah fenomenologi dan realisme metafisik, sedangkan aliran filsafat yang secara implisit mengakomodasikan yang etik dan

\footnotetext{
${ }^{38}$ Nasr, Knowledge and the Sacred, 68.

39 Ibid.

${ }^{40}$ Noeng Muhadjir, "Ilmu Pendidikan Islam (Filsafat dan Paradigma)", dalam Ahmad Tafsir (ed.), Epistemologi untuk Ilmu Pendidikan Islam (Bandung: Fakultas Tarbiyah IAIN Sunan Gunung Djati, 1995), 24-25.
} 
transenden adalah rasionalisme. Pada tataran aksiologisnya, ilmu pendidikan Islam itu ilmu normatif, sehingga perlu diorientasikan kepada nilai (values) baik yang insânîah (berkembang bersama budaya manusia, developed and internalized within the community) maupun yang ilâhîah (diwahyukan, revealed).

Ketiga adalah tataran tesis. Tesis dimaksud adalah tesis epistemologis. Tesis epistemologis ini dipilah menjadi beberapa postulat, yaitu:

1. Wahyu Allah merupakan kebenaran mutlak.

2. Akal manusia adalah lemah (da $\hat{\imath})$ ), oleh karena itu kebenaran yang dapat dijangkau adalah kebenaran probabilistik.

3. Wujud kebenaran yang dicapai dapat berupa eksistensi sensual, logik, etik atau transendental. Menurut bahasa, wujud kebenaran al-Qur'ân tersebut bisa berupa âyah, ishârah, budan dan raḥmah. Keempat hal tersebut bukan empat yang ganda, akan tetapi empat strata atau empat faset.

4. Karena kebenaran yang dapat dicapai manusia adalah kebenaran probabilistik, maka model logika pembuktian kebenaran yang tepat adalah model logika probabilistik.

5. Untuk pemahaman hubungan antarmanusia dan antara manusia dengan alam, sejauh tidak berkaitan dengan nilai, maka model pembuktian induktif-probabilistik dapat digunakan.

6. Untuk pemahaman beragam hubungan tersebut di atas, bila terkait pada nilai model pembuktian deduktif-probabilistik dapat digunakan.

7. Untuk menerima kebenaran mutlak nass, model logika reflektifprobabilistik dengan terapan tematik lebih tepat digunakan.

Terlihat di sini bahwa paradigma ilmu pendidikan Islam yang dikembangkan oleh Noeng Muhadjir agak berbeda dari paradigma ilmu pendidikan Islam yang ditarik dari pemikiran Nasr. Dalam pemikiran Noeng Muhadjir, asumsi dan postulasi yang dipakai untuk mengembangkan ilmu pendidikan Islam diambil dari filsafat Barat, terutama sekali rasionalisme dan realisme metafisik, walaupun kemudian diberi dasar-dasar Islami. Meskipun demikian perlu dicatat bahwa tawaran semacam ini kurang mengakar pada tradisi filsafat Islam dan filsafat ketimuran, bahkan mengadopsi tradisi filsafat Barat. Pengadopsian seperti ini tentunya sedikit berbahaya karena bisa menimbulkan bias ontologis, epistemologis dan aksiologis pada 
bangunan ilmu pendidikan Islam, yang dari semula sebenarnya diusahakan dibangun atas pandangan dunia (Weltsanchaunng) Islam.

Sementara itu pemikiran pendidikan Islam Nasr dikembangkan, secara khusus, atas dasar tradisi filsafat Islam, terutama sekali filsafat iluminis (ishrâqu) yang, antara lain, melihat bahwa alam terpancar dari Tuhan via "Akal Aktif” (al-'aql al-fa'ấ). Oleh karena itu, semua yang ada di alam, walaupun berbeda-beda, adalah satu karena berasal dari satu sumber dan secara lebih luas dibangun atas dasar filsafat perenial, yang memandang aspek eternal dan perenial dari segala sesuatu. Konstruk pemikiran Nasr yang seperti ini menjadikan bangunan ilmu pendidikan Islam yang ia kembangkan memiliki perberbedaan dengan yang dikembangkan oleh pemikir-pemikir Muslim yang mengadopsi tradisi filsafat Barat.

\section{Upaya Rekonstruksi Sistem Pendidikan Islam}

Para ahli ilmu pendidikan telah banyak membuat sistematika studi ilmu pendidikan, di antaranya yang terkenal adalah sistematika Lavengeld. Dalam bukunya Beknote Teoretische Paedagogik, Lavengeld menyebutkan empat faktor pendidikan, yaitu tujuan, anak didik, pendidik, dan alat pendidikan. Kemudian Sigid menambahkan faktor kelima, yaitu lingkungan (milieu, circumstance).$^{41}$ Kelima faktor tersebut tidak bisa berdiri sendiri, namun kesemuanya saling mempengaruhi dan berhubungan satu sama lain. ${ }^{42}$

\section{Tujuan Pendidikan Islam}

Paling tidak, ada beberapa hal yang membuat tujuan dalam pendidikan Islam urgen untuk dirumuskan. Ahmad D. Marimba, sebagaimana dikutip Abuddin Nata, ${ }^{43}$ menyebutkan empat fungsi tujuan pendidikan Islam. Pertama, tujuan berfungsi mengakhiri usaha. Kedua, tujuan berfungsi mengarahkan usaha, tanpa adanya antisipasi (pandangan ke depan) kepada tujuan, penyelewengan akan banyak terjadi dan kegiatan yang dilaksanakan tidak akan berjalan secara efisien. Ketiga, tujuan dapat berfungsi sebagai titik pangkal untuk mencapai tujuan-tujuan lain, yaitu tujuan-tujuan lanjutan dari tujuan pertama. Keempat, fungsi dari tujuan ialah memberi nilai pada usaha itu.

\footnotetext{
${ }^{41}$ Achmadi, "Islam sebagai Paradigma Ilmu Pendidikan”, 21.

42 Sutari Imam Barnadib, Pengantar Imu Pendidikan Sistematis (Yogyakarta: Andi Offset, 1995), 36.

43 Abudddin Nata, Filsafat Pendidikan Islam I (Jakarta: Logos, 1997), 45-46.
} 
Menurut Nasr, pendidikan Islam bukan hanya bertujuan untuk melatih pikiran melainkan juga melatih seluruh wujud sang person, sebab pendidikan Islam tidak pernah memisahkan pelatihan pikiran dari pelatihan jiwa dan keseluruhan pribadi seutuhnya. Ia tidak pernah memandang alih pengetahuan dan pemerolehannya absah tanpa dibarengi pemerolehan kualitas-kualitas moral dan spiritual. Malahan pemilikan pengetahuan tanpa kualitas-kualitas ini dianggap berbahaya, sehingga seorang penyair dari Persia, Sana'i, menyebut orang yang mempunyai pengetahuan tanpa keutamaan moral dan spiritual sebagai pencuri. $^{44}$

Dengan demikian, tujuan pendidikan menurut Nasr merujuk pada totalitas manusia yang mencakup aspek rasional, moral dan spiritual. Konsepsi tentang tujuan pendidikan yang demikian kiranya senada dengan yang dikemukakan para pakar lain semisal Al-Attas yang menyatakan bahwa tujuan pendidikan adalah bukan untuk mewujudkan warga negara yang baik, namun untuk mewujudkan manusia yang "baik" yakni, manusia paripurna (al-insân al-kâmil) ${ }^{45}$ yang bercirikan universalis dalam wawasan dan otoritatif dalam ilmu yakni sesuai dengan fungsi diciptakannya manusia di mana ia membawa dua misi, yaitu sebagai khalîfat Allâh fì al-ard dan sebagai hamba Allah ('abd Allah).

Untuk menjadi khalifah, manusia harus mempunyai kemampuan konseptual-intelektual, hal itu antara lain bisa dilihat dari kasus Adam (wa 'allama Âdam al-asmâ' kullahâ). Adapun fungsi manusia sebagai 'abd antara lain didasarkan pada firman Allah: Dan Tidaklah Aku ciptakan jin dan manusia kecuali agar mereka menyembah (ibadah) kepada-Ku. (Q.S. al-Dhâriyât [51]: 56). Esensi 'abd adalah ketaatan, ketundukan dan kepatuhan yang semua itu hanya diberikan kepada Allah. Dengan demikian ada perbedaan aksentuasi antara terma 'abd dan khalifah di mana terma 'abd mengaksentuasikan pada ketaatan dan kepatuhan, sementara terma yang disebut terakhir mengaksentuasikan nada kebebasan dan kreativitas.

Dengan demikian kedudukan manusia di alam raya ini di samping sebagai khalifah yang memiliki kekuasaan untuk mengolah alam dengan menggunakan segenap daya dan potensi yang dimilikinya juga sekaligus sebagai 'abd dalam arti bahwa seluruh usaha dan aktivitasnya

44 Seyyed Hossein Nasr, Islam Tradisi, terj. Luqman Hakim (Bandung: Pustaka, 1994), 128.

45 Al-Attas, Konsep Pendidikan dalam Islam, 10. 
itu harus dilaksanakan dalam rangka ibadah kepada Allah. Untuk dapat pelaksanakan fungsi kekhalifahan dan ibadah ini dengan baik manusia perlu diberikan pendidikan dan pengajaran. Ini menunjukkan bahwa konsep kekhalifahan dan ibadah dalam al-Qur'ân erat kaitannya dengan pendidikan. Manusia yang dapat melaksanakan fungsi-fungsi yang demikian itulah yang diharapkan muncul dari kegiatan pendidikan. ${ }^{46}$

Sementara Hasan Langgulung juga menegaskan bahwa tujuan pendidikan adalah membentuk al-insân al-kâmil, yang terrefleksikan dalam tiga perilaku, yaitu hubungan baik antara manusia dengan Tuhan, hubungan baik dengan sesama manusia, dan hubungan baik dengan alam sekitar. ${ }^{47}$ Ketiga hal inilah yang disebut dimensi interaksi pendidikan yang merupakan refleksi model manusia al-insân al-kâmil, dan ketiganya harus diperhatikan secara proporsional dengan sinaran aturan Ilahi sehingga tidak menimbulkan sifat destruktif. Interaksi manusia dengan lingkungan alamnya akan menjadi interaksi yang edukatif kalau didasarkan pada interaksi yang Ilahiyah, bukan interaksi satanic yang menghancurkan ${ }^{48}$ yang melahirkan sikap arogan dan ingin mengeksploitasi alam secara membabi buta.

Formulasi tujuan pendidikan oleh Nasr juga bisa kita sandingkan dengan formulasi tujuan pendidikan Islam yang ditawarkan oleh First World Conference on Moslem Education di mana "Pendidikan seharusnya bertujuan untuk mengembangkan secara seimbang totalitas diri manusia dengan melatih jiwa, intelek, daya rasional, perasaan dan indera manusia." Dari rumusan yang dikemukakan para pakar tersebut terlihat bahwa semuanva mengacu pada konsep kesempurnaan manusia yang menjadi tujuan pendidikan, yang antara lain terungkap dan terlihat dengan adanya konsep al-insân al-kâmil. Jika kita teliti lebih jauh, konsep kesempurnaan manusia ini, secara lebih intensif, dapat kita jumpai dalam tradisi pemikiran tasawuf dan filsafat, yang antara lain, memunculkan doktrin al-insân al-kâmil. Walaupun doktrin al-insân al-kâmil, seperti disinyalir oleh beberapa pakar, tidak sepenuhnya milik

\footnotetext{
46 Nata, Filsafat Pendidikan Islam I, 40-41.

47 Achmad Sudja', "Pemikiran Pendidikan Prof. Dr. Hasan Langgulung", dalam Ruswan Thoyib dan Darmuin (eds.), Pemikiran Pendidikan Islam (Yogyakarta: Pustaka Pelajar, 1999), 48.

48 Sodiq Kuntoro, "Pendidikan dalam Perspektif al-Qur'an: Tinjauan Makro", dalam Pendidikan dalam Perspektif al-Qur'an, ed. Yunahar Ilyas dan Muhammad Azhar (Yogyakarta: LPPI UMY, 1999), 68.
} 
Islam, namun setidaknya doktrin ini mendapatkan apresiasi, makna, dan pengembangan lebih lanjut dari pemikir Muslim.

Konsep al-insân al-kâmil dalam tradisi pemikiran tasawuf dan filsafat ditemukan dalam pemikiran Abû Yazîd al-Bistâmî (w. $261 \mathrm{H}$ ), al-Hallâj (w. 309), al-Hâkim al-Tirmidhî (w. 320), Suhrawârdî (w. 587 H) dan mendapatkan apresiasi yang cukup memadai dari Ibn 'Arabî (w. $638 \mathrm{H}$ ), dan di era modern ini, antara lain, mendapatkan perhatian dari Muhammad Iqbal (1877-1938 M). Al-Bisțâmî mengajukan konsep al-walîy al-kâmil yang menurutnya merupakan orang yang telah mencapai ma'rifah yang sempurna tentang Tuhan dan telah terbakar oleh (api) Tuhannya. Menurut al-Hallâj, manusia (Adam) merupkan penampakan Ilahi dari citra Tuhan yang azali kepada Zat-Nya yang mutlak dan tidak mungkin disifati, oleh karena itu Adam diciptakan dengan ș̂rah-Nya. Manusia, dengan demikian, memiliki unsur lâhût dan nâsût. Ketika manusia mengembangkan unsur lâhût-nya dengan baik, ia akan menjadi manusia sempurna. Manusia ideal, menurut al'Tirmidhî, adalah khatam al-awliy â' yang mempunyai ma'rifah yang sempurna tentang Tuhan, sehingga mendapatkan al-quwwah al-ilâhîyah.

Adapun menurut Suhrawârdî, ada tiga klasfikasi al-insân al-kâmil, yaitu pertama, manusia yang mampu mengembangkan kemampuan analitis; kedua, manusia yang mampu mengembangkan kemampuan ketuhanan; ketiga, manusia yang mampu mengembangakan kemampuan analitis dan ketuhanan. Manusia sempurna, kategori terakhir inilah yang paling tinggi, dialah khaliffah Allah dan al-hâkim almuta'âl." Selanjutnya adalah Ibn 'Arabî yang menyatakan bahwa alinsân al-kâmil ada dua level, yaitu adalah alam seluruhnya (al-insân alkabir/makrokosmos) dan level individu (al-insân al-saghîr) mikrokosmos). ${ }^{50}$ Al-insân al-kâmil pada level individu adalah orang yang dapat menyerap nama-nama Ilahi ke dalam dirinya seperti rasul, nabi, wali, dan 'ârif.

Sementara itu Muhammad Iqbal mengemukakan tiga karakter substantif al-insân al-kâmil, yaitu: pertama, karena mempunyai kemampuan untuk ikut serta dalam kehidupan kreatif Tuhan, al-insân al-kâmil merupakan jiwa alam dan bayangan dari al-Ism al-A z̧am. Kedua, ia dipancarkan secara Ilahi dan karena itu menguasai tiga

49 Yunasril Ali, Manusia Citra Ilabi: Pengembangan Konsep Insan Kamil oleb Ibn 'Arabi oleh al-Jili (Jakarta: Paramadina, 1997), 8-11.

50 Abû al-Wafâ' al-Ghanimî al-Taftâzanî, Sufi dari Zaman ke Zaman, terj. Ahmad Rofi' 'Utsmani (Bandung: Pustaka, 1985), 204. 
sumber pengetahuan pengalaman batin, sejarah dan alam yang dipergunakan secara proporsional yang memungkinkannya untuk mengungkap misteri-misteri kehidupan. Ketiga, al-insân al-kâmil mempunyai kesediaan untuk berkorban. ${ }^{51}$ Konsep al-insân al-kâmil Iqbal yang terakhir inilah yang lebih dekat untuk ditarik ke konteks pendidikan Islam karena substansinya lebih realistis dibanding konsep-konsep lain yang terlalu mistis-filosofis karena memang digagas dalam konteks tradisi pemikiran filsafat dan tasawuf. Konsep al-insân al-kâmil Iqbal ini, dengan demikian, lebih mudah untuk disandingkan dengan pemikiran pakar-pakar pendidikan Islam semacam al-Attas dan Langgulung, dan bisa dijadikan sarana dialog untuk memperkaya konsep al-insân al-kâmil dalam pendidikan Islam di samping konsep dari pemikir-pemikir lain.

2. Pendidik

Dalam bahasa Arab dijumpai kata ustâdh, mudarris, mu'allim dan mu'addib. Kata ustâdh berarti teacher (guru), professor (guru besar), jenjang di bidang pendidikan, intelektual, pelatih, penulis dan penyair. Adapun kata mudarris berarti teacher (guru), instructor (pelatih) dan lecturer (dosen). Selanjutnya kata mu'allim berarti teacher (guru), instructor (pelatih), trainer (pemandu), sementara kata mu'addib berarti educator (pendidik) atau teacher in Quranic school (guru dalam lembaga pendidikan al-Qur'ân).

Beberapa kata tersebut di atas secara keseluruhan terhimpun dalam kata pendidik, karena seluruh kata tersebut mengacu pada seseorang yang memberikan pengetahuan, keterampilan dan/atau pengalaman kepada orang lain. Kata-kata yang bervariasi tersebut menunjukkan adanya perbedaan ruang gerak dan lingkungan di mana pengetahuan dan keterampilan diberikan. ${ }^{52}$ Mu'allim biasanya merupakan julukan bagi guru sekolah dasar. Mu'addib (yang arti harfiahnya orang yang beradab atau guru adab) adalah julukan untuk guru-guru sekolah dasar dan menengah, namun dalam periode klasik Islam juga digunakan untuk pengajar di sekolah istana. Shaykh atau guru besar (master) adalah julukan khusus yang menggambarkan keunggulan akademis atau teologis. ${ }^{53}$ Istilah shaykh ini, dalam periode

51 Iskandar Arnel, The Concept of the Perfect Man in the Thought of Ibn 'Arabi and Muhammad Iqbal (Tesis--McGill University Canada, 1997), 60-71.

${ }^{52}$ Nata, Filsafat Pendidikan Islam I, 61-62.

${ }^{53}$ Mehdi Nakosteen, Kontribusi Islam atas Dunia Intelektual Barat, terj. Joko S. Kahhar dan Supriyanto Abdullah (Surabaya: Risalah Gusti, 1995), 63, 77. 
Islam klasik, sering digunakan untuk menunjuk orang yang memiliki kualifikasi mashâkhah (professorship) yang dalam bahasa Arab modern bisa disandingkan dengan istilah ustâdh. Adapun mudarris biasa digunakan untuk menyebut guru dan dosen. Menurut Roihan Ahwan, ${ }^{54}$ mudarris sebagai sebuah istilah yang menunjuk guru mulai dikenal sejak munculnya madrasah Nizamiyah dan dulunya disebut shaykh.

Pendidik, menurut Nasr, bukanlah orang yang sekedar melakukan pengajaran dan penyampaian pengetahuan, namun juga pelatihan totalitas diri siswa ${ }^{55}$ baik pada aspek rasional, moral maupun spiritual. Untuk itu pendidik harus memiliki pribadi yang integral dan memiliki secara seimbang kualitas rasional, moral maupun spiritual, atau, dalam bahasa Nasr, kualitas rasional dan intelektual (yakni, intelek sebagaimana yang dipahami Nasr dan tradisi Islam). Dengan kata lain, pendidik seharusnya berkualitas dan profesional serta memiliki pikiran-pikiran yang kreatif dan terpadu. ${ }^{56}$

Lebih jauh lagi, Nasr melihat bahwa pendidik yang paling baik adalah bijaksanawan (sage/bâkim) yang biasanya merupakan sosok generalis, mengetahui berbagai cabang ilmu dan bisa melihat kesatuan ilmu bagaikan cabang yang banyak dari satu pohon, yang batangnya ialah kebijaksanaan yang menjelma dalam diri orang bijak tersebut. Seorang hâkim selalu menanamkan kesatuan ilmu dalam pikiran anak didiknya dengan mengajarkan semua ilmu, walaupun ilmu itu beragam tapi memiliki prinsip dasar yang sama.

Sebagai akibat logis dari doktrin Islam yang menekankan kesatuan segala sesuatu di alam ini, termasuk di dalamnya ilmu pengetahuan, ilmuwan-ilmuwan Muslim masa awal sering disebut ḅakim yang mendalami semua cabang ilmu pengetahuan, dan secara natural tidak memusatkan perhatiannya pada satu bidang tertentu. Spesialisasi yang melupakan kesatuan dan hierarki ilmu bisa dibandingkan dengan (perbuatan) mengenal tangan manusia dengan melunakan kaki dan otot-otot lain yang penting bagi kehidupan. Dalam hal ini, para ḩâkim menjadikan ilmuwan multi-disiplin Yunani sebagai model. Ilmuwanilmuwan Muslim menganggap spesialisasi ilmiah sebagi suatu

\footnotetext{
${ }^{54}$ Roihan Achwan, "Konstruksi Filosofis Pendidikan Islam", Abdul Munir Mulkhan (ed.), Religiusitas Iptek (Bandung: Pustaka Pelajar. 1998), 68.

${ }^{55}$ Nasr, Islam Tradisi, 126-128.

56 Muhaimin, Kontroversi Pemikiran Fąlur Rabman: Studi Kritis Pembaharuan Pendidikan Islam (Cirebon: Pustaka Dinamika, 1999) 6.
} 
kekurangan, mirip dengan orang yang cacat fisik. Menurut teosofi Islam yang mengatur semua aspek budaya Muslim, para hâkim menghubungkan matematika, filsafat, ilmu kedokteran, sains, dan hukum, serta selalu mencoba mengaitkan teori-teori dan informasi setiap cabang kepada totalitas pengetahuan universal. Semasa kekhalifahan Bani 'Abbâsi>yah, dunia Islam melahirkan banyak ilmuwan Muslim multidisipliner yang pantas kita hormati dan jadikan guru. ${ }^{57}$

Dengan demikian, pendidik yang baik harus mempunyai kematangan intelektual dan emosional serta spiritual, dan lebih baik lagi jika dia adalah seorang hâkim yang bisa menghayati kesatuan dan hierarki ilmu. Sosok pendidik dan ilmuwan yang memiliki pikiranpikiran yang kreatif dan terpadu serta memiliki pengetahuan yang luas dan mendalam seperti itu, tidak bisa tidak, lahir dari sistem dan lingkungan pendidikan yang melihat adanya hubungan fungsional antara al-'ulum al-naqlìyah dan al-'ulum al-'aqlîyah. ${ }^{58}$

\section{Peserta Didik}

Peserta didik adalah objek pendidikan, sehingga harus diperhatikan secara seksama agar proses pendidikan berjalan lancar dan berhasil. Kepada peserta didik perlu ditanamkan dasar-dasar Islam, terutama sekali sejarah sakral masa awal Islam yakni sejarah Nabi dan para sahabat. Peserta didik juga dikondisikan untuk mempelajari tradisi mereka dan tradisi pemikiran lain dari sudut pandang tradisi mereka sendiri, sehingga mereka tidak menjadi orang yang tercerabut dari akar tradisionalnya dan mengalami keterpecahan kepribadian (splitpersonality).

Dalam hal ini pandangan Nasr juga bersesuaian dengan pandangan holisme dalam kurikulum yang berusaha memperlakukan siswa sebagai individu yang utuh dan mendidik mereka tentang kehidupan sebagai keutuhan serta mencintakan lingkungan belajar yang memungkinkan siswa mengembangkan diri menjadi manusia yang memiliki integritas diri yang kokoh. $^{59}$ Rendahnya kualitas

57 Charles Michael Stanton, Pendidikan Tinggi dalam Islam, terj. Afandi dan Hasan Asari (Jakarta: Logos Publishing House, 1994), 89.

${ }^{58}$ Muhaimin et al., Kontroversi Pemikiran Fazlur Rabman, 6.

${ }^{59}$ Ibnu Hadjar, "Pendekatan Holistik dalam Pendidikan Islam: Sebuah Upaya Untuk Efektifitas Pelaksanaan Kurikulum”, dalam Ismail SM. et.al., Paradigma Pendidikan Islam (Yogyakarta: Fakultas Tarbiyah Bekerja Sama dengan Pustaka Pelajar, 2001), 126. 
intelektual anak didik dan munculnya pribadi-pribadi yang pecah sehingga dijumpai, misalnya, seorang Muslim yang saleh dan taat namun pada saat yang sama ia bisa menjadi pemeras, penindas, koruptor, atau melakukan perbuatan tercela lainnya yang menjadi fenomena umum di negeri-negeri Muslim saat ini. Menurut Fazlur Rahman, sebagaimana dikutip Muhaimin $\mathrm{dkk}^{60}{ }^{6}$ hal ini disebabkan belum berhasilnya penghapusan dikotomi antara ilmu-ilmu agama dan ilmu-ilmu umum.

\section{Alat Pendidikan}

Alat pendidikan adalah segala sesuatu yang secara langsung dan sengaja diadakan untuk membantu dan mempermudah tercapainya tujuan pendidikan. ${ }^{61}$ Oleh karena alat pendidikan cakupannya begitu luas mencakup benda dan non-benda, maka pada tulisan ini alat pendidikan lebih dimaksudkan sebagai alat dalam kategori non-benda dan terutama sekali difokuskan pada metode dan materi.

a. Metode pendidikan Islam

Paling tidak, dari tulisan-tulisan Nasr, bisa ditarik benang merah bahwa dia sangat menekankan metode yang berbasiskan tradisional, seperti metode oral-transmission (transmisi lisan), modeling (keteladanan), pembimbingan terutama sekali dalam pendidikan sufi, penalaran logis dan dialog, serta kontemplasi yang sangat dominan pada kalangan sufi. Nasr melihat bahwa metode-metode tradisional tersebut yang bisa membentuk karakter Muslim yang utuh dengan kepribadian yang tidak terpecah dan tidak melupakan akar tradisionalnya.

b. Materi pendidikan Islam

Dalam pandangan Nasr, ada dua kelompok ilmu yang harus diberikan kepada peserta didik, yaitu ilmu naqlì seperti sharî‘ah, fiqh, tafsîr, ta'mîl, hạaîth dan sejarah Islam serta ilmu 'aqlî seperti logika, matematika, ilmu kealaman dan filsafat. Pembagian ilmu itu terrefleksikan dalam lembaga pendidikan Islam tradisional yang sebagian besar mengajarkan kedua ilmu tersebut secara integral. Ilmu 'aqlî tidak dapat dipisahkan kaitannya dengan agama, bahkan di puncak ilmu 'aqli berdiri filsafat atau kebijakan Ilahi (al-hikmah alilâbîyah). ${ }^{62}$

Kategori ilmu yang perlu diajarkan, yang ditawarkan oleh Nasr, dalam banyak hal mengambil klasifikasi yang disusun oleh para pakar

\footnotetext{
${ }^{60}$ Muhaimin et al., Kontroversi Pemikiran Fazlur Rabman, 111.

${ }^{61}$ Barnadib, Pengantar Ilmu Pendidikan Sistematis, 95.

${ }^{62}$ Nasr, Islam Tradisi, 126-128.
} 
semacam al-Farâbî dan Ibn Khaldûn. Al-Farâbî, misalnya, mengemukakan klasifikasi ilmu yang secara garis besar dibagi menjadi ilmu bahasa, logika, ilmu-ilmu persiapan dan fisika dan metafisika, sementara Ibn Khaldûn mengategorikannya menjadi dua kelompok besar, yaitu ilmu-ilmu filosofis dan intelektual (al-ulûm al-'aqlîyah) dan ilmu-ilmu yang disampaikan (al-ulûm al-naqlîyab). ${ }^{63}$ Dalam alMuqaddimah, Ibn Khaldûn meneliti seni dan ilmu di dunia Islam dan mendefinisikan tujuan serta jangkauan setiap disiplin ilmu. Meskipun al-Muqaddimah ini tidak dipelajari secara universal pada periodeperiode sesudahnya, klasifikasi yang dibuatnya memuat secara ringkas rencana yang mengatur pengkajian seni dan ilmu pada sekolah agama Islam sepanjang abad-abad yang lampau. Meskipun banyak sekolah ini, khususnya di kalangan Sunni, tidak mempelajari semua subjek yang disebut dan diperinci oleh Ibn Khaldûn, namun mereka biasanya menerima dasar klasifikasinya. ${ }^{64}$

Pembagian ilmu menjadi dua kelompok besar ini banyak terlihat dalam pemikiran Islam. Al-Ghazâlî, misalnya, yang hidup dua abad sebelum Ibn Khaldûn, membagi ilmu dari segi kewajiban mencarinya menjadi, yaitu fard 'ayn dan fard kifâyah, dan dari segi sumbernya menjadi al-ulum al-shariýah dan al-ulum ghayr al-shariyah. Sementara itu, Konferensi Internasional tentang Pendidikan Islam yang kedua membagi ilmu yang berkembang dan perlu dipelajari di dunia Islam menjadi perennial knowledge dan acquired knowledge. ${ }^{65}$

Dengan demikian Nasr melihat bahwa ilmu itu pada dasarnya satu dan tersusun hierarkis, karena itu tidak selayaknya dikotak-kotakkan (baca: dikotomi ilmu). Kaum Muslimin tradisional tidak pernah memisahkan kedua jenis ilmu tersebut (ilmu 'aqhî dan ilmu naqui), bahkan mengintegrasikannya secara apik sehingga menghasilkan sosok ilmuwan yang utuh, seperti terlihat pada sosok Jâbir b. Hayyan, al-Khawarizmî, Ibn Khaldûn, Ibn Sînâ dan lainnya.

Islam sejak dini selalu menampakkan kedamaiannya dengan pengetahuan. Hingga abad ke-11 tidak ada bukti bahwa the first wave of Hellenism disambut dengan antagonisme dalam sejarah pemikiran Islam. Dengan kata lain, munculnya dikotomi ilmu agama dan non-

\footnotetext{
${ }^{63}$ Nurcholish Madjid (ed.), (ed.). Khazanah Intelektual Islam (Jakarta: Bulan Bintang, 2007), 296-332.

${ }^{64} \mathrm{Nasr}$, Science and Civilization in Islam, 63.

65 Ali Ashraf, Horison Baru Pendidikan Islam, terj. Sori Sireear (Jakarta: Pustaka Firdaus, 1996), 25-26.
} 
agama adalah fenomena kemudian. Fenomena dikotomi antara ilmu agama dan ilmu umum nampak pada abad ke-13. Madrasah Nizâm alMulk, misalnya, hanya mengkhususkan diri pada pengembangan ilmuilmu agama dan kurang memperhatikan ilmu-ilmu umum. ${ }^{66}$ Pemisahan ini, menurut Azyumardi Azra, ${ }^{67}$ terjadi ketika berlangsung kecelakaan sejarah (bistorical accident) dalam sejarah Islam, yaitu ketika ilmu-ilmu umum mendapat serangan hebat terutama sekali dari fuqabâa' yang mengklaim dirinya sebagai guardian of God given law. Sementara itu Shodiq Abdullah ${ }^{68}$ mengemukakan bahwa secara historis persoalan dikotomi ilmu dalam dunia pemikiran Islam dapat dilacak dari adanya dua arus besar yang menyelimuti upaya rekonstruksi pemikiran Islam. Dua arus besar itu adalah stagnasi pemikiran Islam Abad Pertengahan dan supremasi metode penelitian kuantitatif-positivistik dalam dunia Islam. Stagnasi pemikiran Islam memberikan ekses negatif terhadap bangunan epistemologi ilmu dalam Islam, sedangkan supremasi metode kuantitatif-positivistik mengikis pandangan dunia tradisional serta menafikan dimensi spiritual; sebuah dimensi yang tidak dapat dipisahkan dari bangunan epistemologi Islam.

Menurut hemat penulis, konsepsi Nasr tersebut merupakan sesuatu yang penting dan perlu diaplikasikan dalam konteks kekinian juga keindonesiaan. Ketika dunia Islam mengalami krisis dan keterbelakangan di hampir segala bidang (karena melihat bahwa ilmu terkotakkan menjadi ilmu agama dan ilmu umum yang berdiri secara terpisah dan asumsi ini akhirnya menyebabkan muatan materi lembaga pendidikan Islam berbeda dari muatan materi lembaga pendidikan umum), maka konsepsi ilmu Nasr yang mendasarkan pada kesatuan dan hierarki ini perlu ditengok, dikaji ulang secara lebih komprehensif, dan diterapkan secara ekstensif, sehingga diharapkan bisa mengatasi krisis dan ketertinggalan dunia Islam.

Pandangan Nasr ini sesuai dengan konsep kurikulum holistik. Konsep paling mendasar dalam kurikulum holistik ini adalah kesalinghubungan antara kenyataan. Pandangan holistik menyadari bahwa kenyataan terdiri dari bagian-bagian. Namun demikian, bagianbagian tersebut tidak terlepas dan terasing, namun saling berhubungan

\footnotetext{
74 Abdurrachman Mas'ud, "Pendidikan dan Ilmu Pengetahuan dalam Islam", dalam Ismail SM. (ed.), Paradigma Pendidikan Islam (Yogyakarta: Pustaka Pelajar, 2001), 1214.

${ }^{67}$ Azra, "Rekonstruksi Kritis Ilmu dan Pendidikan Islam“, 78-79.

${ }^{68}$ Abdullah, "Rekonsiliasi Epistemologi“", 97-98.
} 
satu sama lain dalam satu kesatuan yang utuh. Atas dasar konsep dasar kurikulum holistik tersebut, Jack Miller, sebagaimana dikutip oleh Ibnu Hadjar, mengatakan:

Fokus dari pendidikan holistik adalah hubungan-hubungan antara berpikir linier dan intuitif, hubungan antar pikiran dan jasad, hubungan antara berbagai ranah pengetahuan, hubungan antara individu dan masyarakat, dan hubungan antara diri (self) dan diri (self). Dalam kurikulum holistik, siswa menguji hubungan-hubungan ini sehingga meningkatkan keterampilan yang diperlukan untuk mentransformasikan hubuingan-hubungan tersebut bila diperlukan. ${ }^{69}$

Secara ringkas, prinsip-prinsip dasar dari pandangan holisme adalah sebagai berikut:

a. Ada kesalinghubungan antar kenyataan dan kesatuan yang mendasar dari alam ini.

b. Ada hubungan yang dalam (deep relationship) antara diri seseorang dan kesatuan tersebut.

c. Untuk melihat kesatuan ini perlu menggunakan intuisi melalui kontemplasi dan meditasi.

d. Nilai muncul setelah melihat dan menyadari hubungan antarkenyataan tersebut.

e. Perwujudan dari kesatuan di antara manusia akan mendorong pada kegiatan sosial untuk melawan ketidakadilan dan penderitaan sesama manusia. ${ }^{70}$

Menurut hemat penulis, kurikulum holistik dalam banyak hal bersesuaian dengan pemikiran Nasr karena sama-sama dibangun atas dasar filsafat parenial yang memandang bahwa segala sesuatu dalam alam ini merupakan bagian dari dan saling terkait dalam satu kesatuan yang utuh.

\section{Lingkungan pendidikan}

Lingkungan pendidikan Islam antara lain meliputi keluarga, masyarakat dan sekolah yang kesemuanya memberikan pengaruh tersendiri bagi perkembangan peserta didik. Oleh karena itu, kesemuanya harus diberi perhatian yang proporsional dalam rangka mewujudkan peserta didik yang berkepribadian utuh. Lebih jauh, jika kita tarik dari pemikiran Nasr, ketiga lingkungan pendidikan Islam tersebut harus tersinari dan merepresentasikan semangat tradisional.

${ }^{69}$ Hadjar, "Pendekatan Holistik", 126-127.

${ }^{70}$ Ibid. 


\section{Penutup}

Ilmu Islam, secara ontologis, dibangun atas dasar metafisika Islam yang mengakui adanya hierarki realitas dan kesalinghubungan antara segala sesuatu. Epistemologi ilmu Islam adalah berdasarkan pada intelek dan akal yang bekerja secara simultan dan kooperatif. Sedangkan secara aksiologis, ilmu Islam mengacu pada nilai-nilai tradisional. Ilmu Islam dibangun atas dasar ide kesatuan yang merupakan inti wahyu Islam. Ide kesatuan ini bukan hanya dalam praanggapan dasar ilmu Islam, namun juga dalam pengungkapan dan penerapan ilmu tersebut. Prinsip Islam, yang mengakui adanya tatanan hierarkis dalam realitas, juga memberikan warna tersendiri terhadap ilmu Islam yang tercermin dengan adanya pengakuan dan penerapan hierarki ilmu. Dengan demikian terlihat bahwa ilmu Islam dibangun atas pandangan dunia Islam yang bertumpukan pada wahyu, dan mendapatkan penjelasan secara memadai oleh akal dan intelek sehingga membentuk bangunan tersendiri.

Ilmu Islam berlandaskan metafisika Islam mengakui bahwa alam memiliki ragam kualitas kesucian (sacred qualities) serta adanya hierarki dan interrelasi realitas. Landasan metafisik tersebut menjadikan substansi ilmu pendidikan Islam yang dikembangkan Nasr berbeda dari ilmu pendidikan secara umum. Ilmu pendidikan Islam, menurut Nasr, mencakup beberapa poin pokok berlandaskan metafisika Islam, bersemangatkan eternalitas, dan termanifestasikan dalam aktivitas pendidikan yang memperhatikan segenap aspek pendidikan. Sementara itu epistemologi ilmu pendidikan Islam yang dikembangkan Nasr bercorak teosentris, yang didasarkan atas tiga sumber pengetahuan, yaitu wahyu, intelek dan akal, yang kesemuanya saling terkait. Adapaun secara aksiologis, ilmu pendidikan Islam dijiwai oleh nilai-nilai tradisional.

Pemikiran Nasr tentang ilmu juga bisa ditarik untuk menata ulang sistem pendidikan Islam. Tujuan pendidikan Islam, menurut Nasr, mengacu dan mengarah pada totalitas manusia yang mencakup aspek rasional, moral dan spiritual. Metode pendidikan yang dikembangkan Nasr berbasiskan tradisional seperti oral-transmission, modelling, penalaran logis dan sebagainva. Materi pendidikan Islam mencakup ilmu-ilmu naqlî dan ilmu-ilmu 'aqlî harus diberikan secara seimbang. Pendidik, dalam perspektif Nasr, harus memiliki kematangan intelektual, emosional dan spiritual, yang model tertingginya bisa dilihat dalam sosok hakim. Peserta didik diharapkan tidak lepas dari 
akar tradisinya, sehingga bisa memahami dan mengimplementasikan ilmu Islam secara baik. Dus, konsepsi ilmu Nasr yang berbasiskan pada perspektif dan pemikiran tradisonalnya merupakan hal yang penting dan bisa diterapkan untuk membangun paradigma ilmu pendidikan Islam dan juga sistem pendidikan Islam yang sampai saat ini belum mendapat penjelasan yang memadai dari pakar pendidikan Islam.

\section{Daftar Rujukan}

Abdullah, Shodiq. "Rekonsiliasi Epistemologi: Ikhtiar dalam Mengatasi Dikhotomi Ilmu dalam Pendidikan Islam", Abdul Khaliq, dkk (ed.), Paradigma Pendidikan Islam. Yogyakarta: Pustaka Pelajar, 2001.

Achmadi. "Islam sebagai Paradigma Ilmu Pendidikan", dalam Ismail SM (ed.), Paradigma Pendidikan Islam. Yogyakarta: Pustaka Pelajar, 2001.

Achmadi. Ilmu Pendidikan Islam 1. Salatiga: Fakultas Tarbiyah IAIN Walisongo Salatiga, 1987.

Achwan, Roihan. "Konstruksi Filosofis Pendidikan Islam", Abdul Munir Mulkhan (ed.), Religiusitas Iptek. Bandung: Pustaka Pelajar. 1998.

Ahmad Ludjito, "Pendekatan Integralistik Pendidikan Agama", dalam Chabib Thoha (ed.), Reformulasi Filsafat Pendidikan Islam. Yogyakarta: Pustaka Pelajar, 1996.

Al-Attas, Syed Muhammad Naquib. Konsep Pendidikan dalam Islam, terj. Haidar Baqir. Bandung: Mizan, 1994.

Ali, Yunasril. Manusia Citra Ilabi: Pengembangan Konsep Insan Kamil oleh Ibn 'Arabi oleh al-Jili. Jakarta: Paramadina, 1997.

Arnel, Iskandar. The Concept of the Perfect Man in the Thought of Ibn 'Arabi and Muhammad Iqbal. Tesis--McGill University Canada, 1997.

Ashraf, Ali. Horison Baru Pendidikan Islam, terj. Sori Sireear. Jakarta: Pustaka Firdaus, 1996.

Azra, Azyumardi. "Rekonstruksi Kritis Ilmu dan Pendidikan Islam", dalam M. Anies (ed.), Religiusitas IPTEK. Yogyakarta: Pustaka Pelajar, 1998.

Bahm, Archie J. Axiology. New York: World Books, 1980.

Barnadib, Sutari Imam. Pengantar Ilmu Pendidikan Sistematis. Yogyakarta: Andi Offset, 1995.

Beerling. Pengantar Filsafat Ilmu, terj. Soejono Soemargono. Yogyakarta: Tiara Wacana, 1990. 
Edward, Paul (ed.). Encyclopedia of Philosophy, Vol. 3. New York: Macmillan Publishing Company 1972.

Gie, The Liang. Ilmu dalam Perspektif Moral, Sosial, dan Politik. Yogyakarta: Liberty, 1991.

Hoodbhoy, Pervez. Islam and Science. Malaysia: S. Abdul Majeed \& Co, 1993.

Hadjar, Ibnu. "Pendekatan Holistik dalam Pendidikan Islam: Sebuah Upaya Untuk Efektifitas Pelaksanaan Kurikulum", dalam Ismail SM. et.al., Paradigma Pendidikan Islam. Yogyakarta: Fakultas Tarbiyah Bekerja Sama dengan Pustaka Pelajar, 2001.

Ismail SM, et al., Paradigma Pendidikan Islam. Semarang: Pustaka Pelajar dan Fakultas Tarbiyah IAIN Walisongo, 2001.

Jalal, Abdul Fattah. Asas-asas Pendidikan Islam, terj. Herry Noer Ali. Bandung: Diponegoro, 1988.

Kattsoff, Louis O. Pengantar Filsafat, terj. Soejono Soemargono. Yogyakarta: Tiara Wacana, 1992.

Kuntoro, Sodiq. "Pendidikan dalam Perspektif al-Qur'an: Tinjauan Makro", dalam Pendidikan dalam Perspektif al-Qur'an, ed. Yunahar Ilyas dan Muhammad Azhar. Yogyakarta: LPPI UMY, 1999.

Lewis, Bernard. Islam and the West. New York: Oxford University Press, 1993.

Madjid, Nurcholish (ed.). Khazanah Intelektual Islam. Jakarta: Bulan Bintang, 2007.

Mas'ud, Abdurrachman. "Pendidikan dan Ilmu Pengetahuan dalam Islam", dalam Ismail SM. (ed.), Paradigma Pendidikan Islam. Yogyakarta: Pustaka Pelajar, 2001.

Muhadjir, Noeng. "Ilmu Pendidikan Islam (Filsafat dan Paradigma)", dalam Ahmad Tafsir (ed.), Epistemologi untuk Imu Pendidikan Islam. Bandung: Fakultas Tarbiyah IAIN Sunan Gunung Djati, 1995.

Muhaimin. Kontroversi Pemikiran Fąlur Rahman: Studi Kritis Pembaharuan Pendidikan Islam. Cirebon: Pustaka Dinamika, 1999.

Nakosteen, Mehdi. Kontribusi Islam atas Dunia Intelektual Barat, terj. Joko S. Kahhar dan Supriyanto Abdullah. Surabaya: Risalah Gusti, 1995.

Nasr, Seyyed Hossein. "Kata Pengantar", dalam Osman Bakar, Hierarki Ilmu: Membangun Kerangka Pikir Islamisasi Ilmu, terj. Purwanto. Bandung: Mizan, 1997.

----. Islam Tradisi, terj. Luqman Hakim. Bandung: Pustaka, 1994.

----. Knowledge and the Sacred. Edinburg: Edinburg University Press, 1981. 
-----. Science and Civilization in Islam. New York: The New American Library, 1970.

Nata, Abudddin. Filsafat Pendidikan Islam I. Jakarta: Logos, 1997.

Rohman, Abdul. "Pendidikan Islam 'Tradisional' di Era Modem", dalam Ruswan Thoyib dan Darmuin (eds.), Pemikiran Pendidikan Islam. Yogyakarta: Pustaka Pelajar, 1999.

Runes, Degobert D. Dictionary of Philosophy. New Littlefield: Adam and Co, 1971.

Santillana, Giorgio de. "Preface", dalam Seyyed Hossein Nasr, Science and Civilization in Islam. New York: The New American Library, 1970.

Stanton, Charles Michael. Pendidikan Tinggi dalam Islam, terj. Afandi dan Hasan Asari. Jakarta: Logos Publishing House, 1994.

Sudja'i, Achmad. "Pemikiran Pendidikan Prof. Dr. Hasan Langgulung", dalam Ruswan Thoyib dan Darmuin (eds.), Pemikiran Pendidikan Islam. Yogyakarta: Pustaka Pelajar, 1999.

Tafsir, Ahmad. Ilmu Pendidikan dalam Perspektif Islam. Bandung: Remaja Rosdakarya, 1994.

Taftâzanî (al), Abû al-Wafâ' al-Ghanimî. Sufi dari Zaman ke Zaman, terj. Ahmad Rofi' 'Utsmani. Bandung: Pustaka, 1985.

Wibisono, Koento. "Ilmu Pengetahuan Sebuah Sketsa Umum Mengenai Kelahiran dan Perkembangannya sebagai Pengantar untuk Memahami Filsafat Ilmu", Makalah, Ditjen Dikti Depdikbud-Fakultas Filsafat UGM Yogyakarta, 1999. 